V ekspresionistično stilno paradigmo (1914-1923) opravila izjemno zahtevno in obsežno delo. Uspelo ji je zapolniti vrzel med ekspresionistično poezijo in dramatiko, do sedaj bolj raziskanima področjema. Študije s področja metaforike zgodnje ekspresionistične kratke proze uvrščajo monografijo na obvezen seznam študijske literature s področja literarne vede, predvsem pa omogočajo nadaljnje raziskovanje ekspresionistične kratke proze $\mathrm{v}$ kasnejšem obdobju.

Črt Močivnik

Celje crt.mocivnik@gmail.com

\section{BESEDOTVORNI TEMATSKI BLOK NA PETNAJSTEM MEDNARODNEM SLAVISTIČNEM KONGRESU V MINSKU (2013)}

Petnajsti mednarodni slavistični kongres je po Ohridu (2008) potekal v beloruskem Minsku v dneh od 20. do 27. avgusta 2013. Udeležilo se ga je okrog petsto slavistov iz blizu štiridesetih držav. Skupaj s predsednico Slovenskega slavističnega komiteja prof. dr. Alenko Šivic Dular se je kongresa udeležilo še sedem jezikoslovcev: Andreja Žele, Irena Orel, Petra Stankovska s Filozofske fakultete Univerze v Ljubljani, Metka Furlan, Silvo Torkar, Andreja Legan Ravnikar z Inštituta za slovenski jezik Frana Ramovša in Irena Stramljič Breznik s Filozofske fakultete Univerze v Mariboru. Z diskusijskimi prispevki v posamezni sekciji pa je sodeloval tudi prof. dr. Janez Dular. Nacionalni prispevki za kongres so bili objavljeni pod skrbnim uredništvom Petra Weissa v prvi številki devetnajstega letnika Jezikoslovnih zapiskov z naslovom Slovensko in slovansko (celotna številka je dosegljiva na naslovu: http://bos.zrc-sazu. si/knjige/JZ\%2019.1\%20\%282013\%29. pdf), v kateri sta svoja prispevka objavila še Mira Krajnc (FF UM) in Matej Šekli (FF UL), ki pa v Minsk nista potovala. Povzetke vseh nastopajočih na kongresu pa je izdal organizator $\mathrm{v}$ dveh obsežnih večjezičnih zbornikih. Prvi je bil namenjen jezikoslovju, drugi pa književnosti, kulturologiji in folkloristiki, oba je uredil tudi organizator kongresa $\mathrm{A}$. A. Lukašanec.

Poleg predstavitev prispevkov v posameznih sekcijah je bilo na tem kongresu mogoče sodelovati tudi $v$ tematskih blokih. Za slovansko besedotvorje ga je organizirala Elena Koriakowcewa in vse zbrane prispevke izdala $\mathrm{v}$ publikaciji z naslovom Stowotwórstwo a nowe style funkcjonalne języków stowiańskich: International Slavistic Comitee Commission on Word Formation (Siedlce 2013). V tematskem bloku so sodelovale jezikoslovke petih držav: Elena I. Koriakowcewa (Poljska, Rusija), Galina P. Neščimenko (Rusija), Ingeborg Ohnheiser (Avstrija), Elena G. Lukašanec (Belorusija), Irena Stramljič Breznik (Slovenija), Elena V. Petruhina (Rusija) in Lidija Arizankovska (Makedonija).

Elena I. Koriakowcewa (9-38) je v svojem prispevku razmišljala o novih besedotvornih načinih in produktivih besedotvornih procesih, kot se izpostavljajo v sodobnih slovanskih jezikih. Pri tem se je osredotočila na uzualne tvorbene procese, kot sta zlaganje in afiksacija (izpeljava, sestavljanje), manj pozornosti pa je namenila novejšim 
tvorbenim postopkom, kot sta na primer prekrivanje (angl. blending) in krnjenje (angl. clipping). Gradivo za analizo je črpala iz besedil aktualne publicistike, oglasov in elektronske komunikacije. Kot je ugotovila, ima leksikalna kreativnost $\mathrm{v}$ tovrstnih besedilih predvsem stilistično vlogo in učinkuje zlasti humorno ali ironično.

Rusinja Galina P. Neščimenko (3966) se je v svoji razpravi posvetila analizi spletne komunikacije, pri tem je izhajala tako iz ontološke kot funkcijske narave spletnega jezika. Razpravljala je o elektronski komunikaciji v luči sodobne javne jezikovne kulture in aktualnih besedotvornih zakonitosti.

Ingeborg Ohnheiser $\mathrm{z}$ Univerze $\mathrm{v}$ Innsbrucku (67-82) je kot dobra poznavalka slovanskega besedotvorja predstavila razvoj pragmatičnih in stilističnih tendenc $\mathrm{v}$ njem, pri čemer se je posebej posvetila rušenju stilističnih meja. Izhajala je iz zbornika Stowotwórstvo/Nominacija, ki ga je tudi uredila (Ohnheiser 2003). Besedotvorne analize in kontrastivne študije tega zbornika so bile posvečene raziskavi in opredelitvi lingvističnih pojavov, kot je t. i. internacionalizacija, pragmatičnim in slogovnim težnjam in težnji $\mathrm{k}$ jezikovni ekonomiji. V tokratnem prispevku je Ohnheiserjeva predstavila razvoj pragmatičnih in stilističnih tendenc, in sicer s posebnim ozirom na ruske $» B e-$ sede leta« (2007-2011).

Elena G. Lukašanec (83-98) je razdelala značilnosti motiviranega besedja $\mathrm{v}$ različnih stilih mladostniške spletne komunikacije. Besedno gradivo za raziskavo je črpala iz spletnih slovarjev, dostopnih na straneh slovonovo.ru in teenslang.su. Lukašančeva je predstavila dva tipa slengovske leksike, in sicer sleng t. i. »igričarjev« ali »gamerjev« ter internetni sleng. Dognala je da, so v internetnem jeziku izjemno pogoste grafično obogatene tvorjenke, $v$ t. i. »igričarskem《 spletnem jeziku pa vladajo številne abreviacije - oboje ima seveda stilistično funkcijo.

Irena Stramljič Breznik (99-109) z mariborske Filozofske fakultete se je $\mathrm{v}$ referatu posvetila novotvorjenkam $\mathrm{v}$ spletnih oglasih, ki so v sodobnem času prežeti z novimi besedami, oblikovanimi po neobičajnih postopkih. Na tak način namreč oglaševalci vplivajo na naslovnika, pritegnejo njegovo pozornost in ga z zanimivimi, atraktivnimi tvorjenkami privabijo k nakupu oz. uporabi storitve. Stramljičeva je raziskala novotvorjeno besedje slovenskega jezika $\mathrm{v}$ tiskanih, televizijskih in spletnih oglasih, ki so bili aktualni med letoma 2009 in 2012. V svojem prispevku je izpostavila leksikalne inovacije, med katere uvršča t. i. potencialne $z$ manjšo in t. i. izvirne tvorbene vzorce $z$ večjo kreativnostjo.

Elena V. Petruhina (110-134) je analizirala besedotvorne značilnosti sodobnega ruskega cerkvenega oz. religioznega diskurza, pri čemer se je osredinila na stilistično funkcijo tvorjenk in morfemov cerkvenoslovanskega izvora ter prikazala vzajemno delovanje besedotvornega, leksikalnega in slovničnega pomena tvorjenk besedil visokega sloga oz. tvorjenk v sodobnih cerkvenih pridigah. Zanimiva je ugotovitev, da imajo zelo pomembno vlogo pri oblikovanju visokega cerkvenega stila zlasti predpone oz. prefiksi.

Profesorica Univerze sv. Cirila in Metoda v Skopju, Lidija Arizankovska (135-145), je predstavila stanje makedonskega jezika, kot ga odražajo tvorjenke v jeziku medijev, zlasti v publicističnih in oglasnih besedilih. Kot ugotavlja Arizankovska je fenomen publicističnega jezika in jezika oglasov 
pogojen s procesom globalizacije in $\mathrm{z}$ vplivom angleščine na eni strani, na drugi pa s težnjo po hitri in afektivni komunikaciji.

Tudi tokratni prispevki so prinesli nekaj zanimivih novih spoznanj in štu- dij, ki so dobrodošla obogatitev vedenja s področja slovanskega besedotvorja.

Ines Voršič, Irena Stramljič Breznik

Univerza v Mariboru ines.vorsic@guest.arnes.si, irena.stramljic@um.si 